\title{
MARTÍN CHAMBI EN BLANCO Y NEGRO
}

Mario Colán

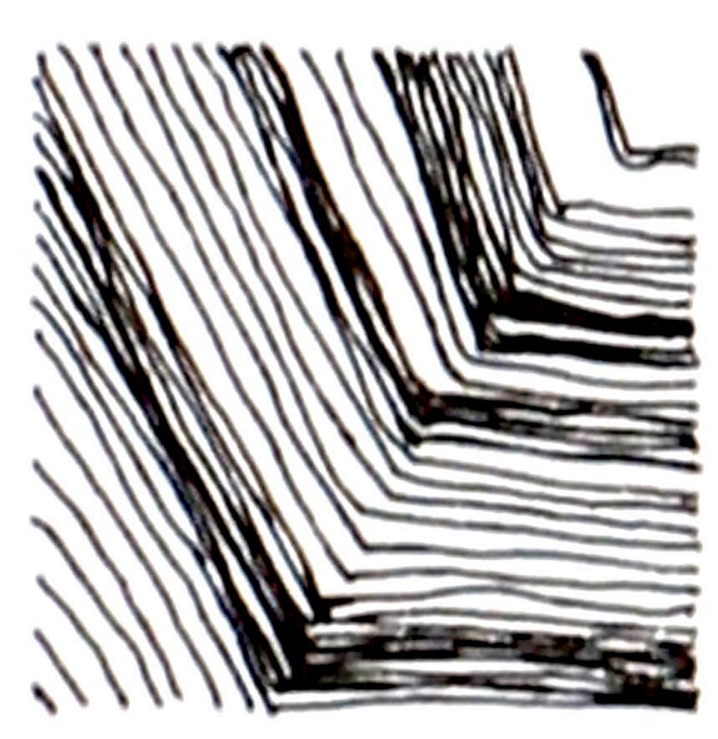

Martín Chambi J. (Coasa, 1876-1973) -fotógrafo de origen puneño- ha sido tema de innumerables publicaciones y exhibiciones a lo largo de nuestra historia reciente. Su obra ha sido expuesta tanto en Lima, Arequipa, como en ese Cusco señorial que conoció la mayor parte de su producción. Muchos historiadores, antropólogos y otros investigadores, desde sus respectivos campos, han hablado de ella, dejando constancia de su increíble valor artístico y etnográfico. Sin embargo, es en este libro de Andrés Garay Albújar en donde el fotógrafo habla - como dice el títuloPor sí mismo.

Esta publicación es una adaptación de la tesis doctoral que Garay presentó y sustentó en la Universidad de Navarra, España, en el año 2001. Esta investigación nos da luces de todo el proceso que atravesó Chambi en el desarrollo de su arte fotográfico. Desde sus orígenes en Coasa, Puno, su posterior viaje a Arequipa, hasta su establecimiento final en Cusco. En cada uno de estos lugares, nos detenemos - guiados por el autor - para ver qué tipo de trabajo hacía el fotógrafo, cuáles eran sus influencias, su técnica y de quiénes aprendió este oficio. 


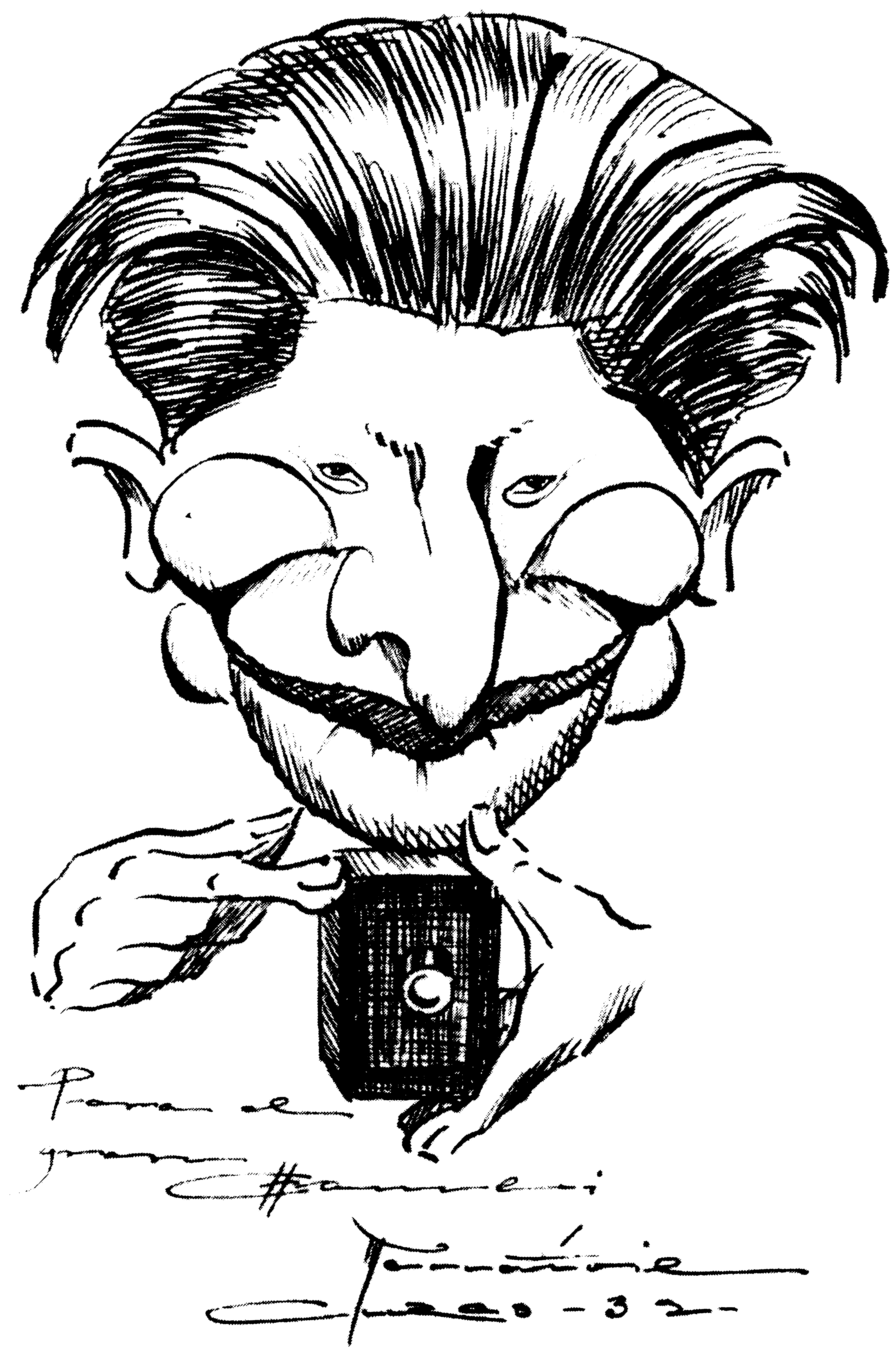

Dedicatoria de Víctor Mendivil, Cuzco, 1932.

Fuente: Martín Chambi por sí mismo, Andrés Garay, 2006 
En su pueblo natal, Chambi tuvo que dejar la escuela en la primaria, puesto que el Perú vivía aún los estragos de la crisis de la posguerra con Chile, viéndose obligado a trabajar desde muy pequeño en un asiento minero. En él, conoció a dos ingleses: Mister Angus y Mister Ferrin, quienes - dice Chambi- «le permitieron observar de cerca ese fenómeno que ellos llamaban fotografía». Incluso - recoge el autor-, fue invitado por ellos a viajar a Inglaterra, a lo que él se negó.

Posteriormente, Martín Chambi-quien contaba ya con diecisiete años- se trasladó a Arequipa, lugar en el que comenzaría su aprendizaje en la técnica fotográfica a manos de Max T. Vargas, en cuyo estudio trabajó por diez años. El fotógrafo puneño decidió mudarse allí porque le habían dicho que en esta ciudad la fotografía estaba mucho más desarrollada que en su pueblo, lo que constataría en el trabajo de estudio que llevó a cabo con Vargas. De éste — nos dice Garay Albújar - no sólo aprendería de técnica, sino también de manejo comercial, pues tenía una amplia clientela en sus estudios de Arequipa y La Paz. Podemos concluir, entonces, que es en Arequipa en donde Chambi se gesta como fotógrafo.

El año 1920 es -para el autor - el momento de escisión para el estudio de la obra de Chambi, ya que es cuando se estableció en Cusco. Y desde allí, desarrolló su más destacada producción; tanto desde el punto de vista artístico -en retratos, por ejemplo_ como comercial -al vender postales con vistas de la Ciudad Imperial, actividad que aprendió cuando trabajó con Max T. Vargas y que era muy difundida como parte del negocio turístico-. En dicha ciudad, desarrolló también una estrecha relación con otros fotógrafos del lugar, tales como Miguel Chani y Manuel Figueroa y Aznar.

Luego, Chambi, Figueroa y Chani ocuparían el estudio que -en principio- fue propiedad de este último —en distintas épocas-; el traspaso de este lugar sería algo común entre los fotógrafos de la época. Los anuncios en revistas que circulaban por aquellos años daban cuenta del trabajo que hacían los mencionados artistas, y le sirven al autor como documentación probatoria de lo dicho líneas arriba.

Martín Chambi fue reconocido, - en su labor fotográfica, en Cuscocomo un gran retratista. Por aquella época, era muy usual vincular la obra de un fotógrafo con la de algún pintor para caracterizar la particularidad del estilo del retrato, razón por la que éste promocionó la técnica que utilizaba como "estilo Rembrandt», que consistía en generar 
altos contrastes - luces muy altas y sombras muy oscuras - a partir de la iluminación, puntual y lateral, sobre el perfil de una persona.

Chambi también realizó proyectos personales de retrato paralelos a su labor comercial; uno de ellos - el de los tipos andinos - respondería -según Garay Albújar - a un interés sociológico o periodístico. Aquí. el autor distingue cómo es que Chambi no interviene en los negativos -a diferencia de los retratos comerciales, en los que su técnica Rembrandt lo obliga a retocar la imagen-, suponiendo que la motivación del fotógrafo es, más que nada, documental. Uno de los ejemplos de este tipo de retrato lo constituye una de sus fotografías más reproducidas y famosas: El gigante.

Por otro lado, además del retrato, Martín Chambi desarrolló otro tipo de fotografía. Para entender su intención, el autor del texto cita -de una entrevista hecha a Chambi, en 1958- lo siguiente:

Desde que empecé a tomar la fotografía en serio, mi ideal fue sólo uno: dar a conocer al mundo toda la belleza natural de mi patria y la imagen tan hermosa de las ruinas que hablan de nuestro pasado histórico, con el fin de promover, en lo posible, de acuerdo a mis medios, el turismo en el Perú.

A partir de esta afirmación, podemos comprender con más claridad su dimensión como paisajista y la razón por la cual se interesó en tomar fotografías de restos arqueológicos.

De todo lo anterior, el autor concluye que Martín Chambi tenía una visión amplia sobre su cultura y de cómo estaba inmerso en ella. Su fotografía en gran formato le ofrece a Garay Albújar los elementos necesarios para el análisis del devenir de su arte, pues al adentrarse en su estudio, en la observación de las placas de vidrio y en las copias hechas por el mismo fotógrafo, percibe la intencionalidad que él le quiere dar a determinado tipo de trabajo.

Una pregunta que brota con respecto a este acercamiento al libro Martín Chambi, por sí mismo es: ¿cuál es la diferencia sustancial entre otras investigaciones acerca de la vida y obra de Martín Chambi y ésta? La respuesta que surge inmediatamente radica en las fuentes que Andrés Garay Albújar utiliza. Creo que nadie, hasta este momento, se había centrado en la real dimensión que tiene para el análisis de la obra de Chambi observar los recortes periodísticos que el fotógrafo iba recopilando 


\section{MARIO COLÁN}

de sí mismo, además de los cuadernos personales de autógrafos, dedicatorias y retratos.

Garay hace un recorrido a través del tiempo con los cuadernos de recortes, las exposiciones del fotógrafo en el Hotel Bolívar, en Lima - por citar alguna-, o cómo la prensa reaccionó ante ellas, ante él, ante ese indio de quien Román Hernández M. escribiría:

Chambi persona, es casi nada. Cuántas veces se le ha visto discurrir por las calles de esta brumosa Lima, midiendo los pasos, de aquí allá desorbitado, turulato en medio del pandemonium del medio en el Jirón de La Unión [...] Chambi no tiene la cara blanca; tiene sí el matiz del bronce andino [...] Pero Chambi artista, es mucha cosa. Es dueño de una magnífica pupila ivaya tesoro! con la que prestamente capta el motivo original.

Después de la revisión de los cuadernos personales y de autógrafos, el autor reflexiona sobre la necesidad de Chambi de pedirles dedicatorias $y$ retratos a sus coetáneos, y concluye planteando que, probablemente, se debía a que el fotógrafo era analfabeto y ésa era la manera que él había encontrado para dejar constancia del valor de su obra y de la importancia de su presencia en el contexto histórico-cultural de ese entonces.

A la vista de lo expuesto en esta breve reseña, la investigación de Garay Albújar nos quiere poner delante de la dimensión humana del artista. En este libro, el análisis fotográfico pasa a un segundo plano, para darle preeminencia a Martín Chambi como personaje. Así, podremos - a partir de este texto- reconstruir la historia personal de uno de los más destacados artistas peruanos del siglo veinte; desde su nacimiento e influencias, hasta su ocaso vital -caminando por las calles de Cusco con sus cámaras de $35 \mathrm{~mm}$, buscando una luz y una sombra, un paisaje, un rostro, o tan solo una vieja calle vacía en la que se pudiese filtrar un rayo de sol-.

Definitivamente, este es un libro capital que nos da nuevas luces sobre Chambi y que, a la vez, corrige ciertas imprecisiones de indagaciones y publicaciones anteriores. Martín Chambi - a través de la obra de Andrés Garay Albújar - se vuelve el protagonista de su propia formación e historia. 